\title{
Federalism and Party Democracy in West Germany
}

\author{
Oscar W. Gabriel \\ University of Mainz
}

\begin{abstract}
According to Gerhard Lehmbruch, there is a growing inconsistency in West Germany between the principles of a federal polity and party democracy, primarily because the former relies on bargaining, and the latter relies on majority rule as a mechanism of conflict regulation. However, comparative analyses have shown that federalism and party competition are not incompatible. Generally, federal structures are neither detrimental nor conducive to the recruitment function of parties. Competence and experience as a parliamentary leader or as a specialist is the most essential precondition for advancement to national executive positions. The integrative capacities of political parties may even be strengthened by the federal division of power. Only in the area of the formulation and implementation of public policy may an inconsistency between the federal system and party democracy arise because the strain on consensus-building inherent in German cooperative federalism may, under specific conditions, prevent the national majority party from converting its programs into public policy.
\end{abstract}

When Gerhard Lehmbruch published his book Party Competition in the Federal System, he pointed to a growing inconsistency between the functioning of the federal state and of party competition. From his point of view, the patterns of competitive conflict regulation in the German party system contradict the tradition of consensual decisionmaking typical of federal systems. ${ }^{\prime}$ From another perspective, Klaus von Beyme evaluates political parties as centralizing forces in modern German history, as opposed to federalism, which is aimed at distributing political and administrative power between the central state and its constituent parts. ${ }^{2}$ Contrary to Lehmbruch and von Beyme, who are mainly concerned about the tensions between consensual federalism and competitive party democracy, empirical analyses in comparative politics by Arend Lijphart clearly demonstrate that the mixed type of competitive party system and consensual federalism is more frequent in stable democracies than the ideal federalist-consensual or competitivecentralist type. ${ }^{3}$ According to William H. Riker, too, a close correspondence

AUTHOR'S NOTE: I am grateful to Richard W. Taylor, Kent State University, and Arthur B. Gunlicks, University of Richmond, for helpful comments. Data presented on the recruiting functions of political parties refer to March 1989.

${ }^{1}$ Gerhard Lehmbruch, Parteienwettbewerb im Bundesstaat (Stuttgart: Kohlhammer Verlag, 1976), p. 16.

${ }^{2}$ Klaus von Beyme, "West Germany: Pluralism and Federalism," International Political Science Review 5 (Winter 1984): 381-397.

${ }^{3}$ Arend Lijphart, Democracies: Patterns of Majoritarian and Consensus Government in Twenty-One Countries (New Haven: Yale University Press, 1984), pp. 211-222; Arend Lijphart, 
between decentralized party systems and partially centralized federalist structures has increasingly developed in modern democracies. ${ }^{4}$

\section{FEDERALISM AS AN ORGANIZATIONAL FRAMEWORK OF WEST GERMAN PARTY DEMOCRACY}

The integration of party democracy and federalism was also part of the constitutional philosophy of the founders of the Federal Republic of Germany. In accordance with the demands of the Allied occupation forces, the founders intended to revitalize the strong tradition of German federalism that goes back to the Holy Roman-German Empire. ${ }^{5}$ At the same time, however, they wanted to institutionalize party democracy as a new legitimate element of constitutional practice. Consequently, Article 20, I of the Basic Law designates federalism as a basic element of the German constitutional system, protected against any kind of legal change. ${ }^{6}$ Contrary to the German cultural tradition of a largely nonpartisan bureaucratic state, the role of political parties was now mentioned explicitly. According to Article 21 of the Basic Law, political parties participate in the formation of public opinion and in the decisionmaking process of the Federal Republic. Their organizational structure has to meet the requirement of intraparty democracy, and they have to accept the leading principles of pluralist democracy. The role of political parties is regulated in detail by a special federal law, the Parteiengesetz, which was enacted in 1967. By recognizing the role of political parties as an essential element of democracy and by trying to integrate party democracy and federalism, the Basic Law established a largely new element in German constitutional thinking as well as in constitutional practice. According to Article 28, I, the basic principles of the national political order apply to the constitutional framework of its constituent parts, including the Länder.

From the beginnings of the Federal Republic of Germany, political parties had to operate in a context essentially characterized by a distribution of political and administrative responsibilities between the central state (Bund) and the Länder. In order to influence political decisions in national and Land politics, party organizations had to correspond, at least roughly, to the federal structure of the larger political system. Some kind of intra-organizational decentralization not only was demanded by the role of parties in their political environment, but also was imposed by law as an element of intraparty democracy and division of power (see sections 6 and 7 Parteiengesetz).

\footnotetext{
"Democratic Political Systems: Types, Cases, Causes, and Consequences," Journal of Theoretical Politics 1 (Spring 1989): 33-48.

${ }^{4}$ William H. Riker, "Federalism," Handbook of Political Science, vol. 5, eds. Fred I. Greenstein and Nelson W. Polsby (Reading, Mass.: Addison Wesley, 1975), pp. 93-173, especially pp. 133-136.

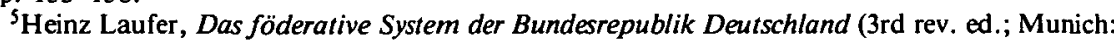
Bayerische Landeszentrale für Politische Bildungsarbeit, 1977), pp. 21-32.

${ }^{6}$ Other constitutionally prescribed and protected principles are democracy, the republic, and the social state.
} 
Due to their distinct organizational traditions, German political parties met this requirement rather differently. The Social Democrats (SPD) traditionally have had a highly centralized organization. The party's structure has deviated markedly from the territorial organization of the larger political system. With a few exceptions, party organizations did not exist at the Land level (Landesverbände), or if they did, they played a limited role in intraparty life. ${ }^{7}$ Special party districts (Bezirke) and sub-districts (Unterbezirke), not organized according to Land boundaries, served as intermediary units between the strong national party organization and its local branches (Ortsvereine). Any efforts to strengthen the role of the Land party organization failed until the 1960s. Since then, Land party organizations have been formed, Land party statutes passed, Land party leaders elected, and Land party headquarters established in addition to the existing organizational framework. ${ }^{8}$ Today, there exist SPD Land organizations with more or less important recruiting and policymaking functions in every Land, but their role still remains limited when compared with the strong Landesverbände of the Christian Democrats (CDU/CSU) and the Liberals (FDP). The latter two were strongly decentralized organizations from their beginnings; the same applies to the Green party established between 1977 and 1980. There are eleven statewide CDU, FDP, and Green organizations in the Länder, including the Bavarian Christian Social Union (CSU), which did not join the CDU national party in 1950, with district organizations roughly corresponding to the administrative districts and county organizations in every county. The CDU/CSU runs local party organizations in almost all cities and rural communities, whereas the smaller Green party and the FDP are present as political organizations only in larger cities. ${ }^{9}$ Up to now, the Land party organizations of the CDU, the FDP, and the Greens have played an essential role in intraparty life.

\section{THE PERFORMANCE OF PARTY FUNCTIONS IN THE FEDERAL SYSTEM}

From different starting points, then, German political parties built up an organizational infrastructure appropriate to fulfill party functions in national and Land politics. Although these functions are somewhat controversial in the theory of political parties, there is a certain degree of consensus among researchers that at least three functions have to be fulfilled in a working party democracy: the recruitment of political leaders, the formulation and im-

\footnotetext{
${ }^{7}$ These exceptions were Bavaria, the city-state of West Berlin, and the small Länder of Schleswig-Holstein and Saarland, which encompassed only one single statewide party district.

${ }^{8}$ For a detailed description of the formation of the Land party organization in RhinelandPalatinate, see Heino Kaack and Ulrich Sarcinelli, "Parteien und Wahlen," 40 Jahre RheinlandPfalz: Eine politische Landeskunde, ed. Peter Haungs (Mainz: Verlag H. Schmidt, 1986), pp. $145-148$.

${ }^{9} \mathrm{~A}$ short description of patterns of party organization is to be found in Wolfgang Rudzio, Das politische System der Bundesrepublik Deutschland (2nd ed.; Opladen: Leske und Budrich, 1987), pp. 146-152.
} 
plementation of public policy, and the integration of the electorate into the political community. ${ }^{10}$ In the following sections we will examine whether the federal organization of the West German political system has any impact on how parties perform these tasks.

\section{The Recruiting Function}

In every democracy, parties play an essential role in recruiting legislative and executive personnel. Given that the issues decided at the polls are not well known in any detail by the electorate, and the voters normally have only a limited knowledge of the qualities of the candidates for leadership positions, party labels serve as a reference point for voters.

Evidently, the recruitment function of political parties is not performed in the same way in federal as in unitary systems. In a federal system consisting of largely autonomous units, the units (states, provinces, Länder, cantons) may provide an opportunity for political participation and party competition that is absent from unitary political systems. This thesis should be analyzed separately with regard to the intraparty recruiting process and to the electoral decision applying to the national and Land political systems.

In addition to the election of local councils and the national parliament, the West German electorate has the right to choose among party candidates for eleven Land assemblies (Landtage). These are, in turn, responsible for choosing Land executives (Landesregierungen) which, therefore, are selected indirectly by the people of the Länder. The number of directly elected Land representatives varies between 50 (Saarland) and 204 (Bavaria), and it totals approximately $1,400.11 \mathrm{~A}$ comparably broad base of independent recruitment agencies does not exist in unitary systems. As a consequence of party competition in the Länder, the citizens of a federal political system exercise participative rights in the recruitment of political leaders not available to the electorate in unitary systems.

In addition, citizens in the Federal Republic may influence indirectly national political decisionmaking by casting their ballots in Land elections, because the Länder are involved in the recruitment of some national officeholders. The president of the Federal Republic is elected by an electoral body consisting of all members of the German Bundestag and an equal number of delegates of the Länder who are elected by the Landtage (Article 54 GG). The Länder play a role in selecting the members of the Federal Constitutional Court (Bundesverfassungsgericht), half of whose members are

\footnotetext{
${ }^{10}$ For a detailed analysis of party functions in democracy see Sigmund Neumann, "Zum vergleichenden Studium politischer Parteien," Beiträge zur allgemeinen Parteienlehre: Zur Theorie, Typologie und Vergleichung politischer Parteien, ed. Gilbert Ziebura (Darmstadt: Wissenschaftliche Buchgesellschaft, 1969), pp. 218-225; Klaus von Beyme, "Krise des Parteienstaates-ein internationales Phänomen?"' Parteien und Bürger: Ansichten und Analysen einer schwierigen Beziehung, ed. Joachim Raschke (Opladen: Westdeutscher Verlag, 1982), pp. 87-100.

${ }^{11}$ The exact number of representatives varies from election to election, due to some special provisions of electoral laws.
} 
elected by the Bundestag and the Bundesrat, respectively (Article 94 GG). These elections, without exception, are partisan. Half of the members of the German Bundestag are selected in voting districts, the other half from separate Land party lists (Landeslisten). The Land electorate shares indirectly in the respective selection processes by allocating power to the competing Land parties. The Land party organizations can exert a strong direct influence on the nomination process. Whereas they usually follow the recommendation of their national party leaders in selecting the president of the Republic and the members of the Constitutional Court, the situation is completely different in the nomination of candidates to the national parliament. In this respect, the effectiveness of the Land party as a recruiting agency largely depends on its autonomy from the influence of the national party organization. Autonomy implies the right of the Land party rank and file to select Land political personnel according to their own preferences.

As many authors have shown, the recruiting function of Land party organizations in drawing up party lists is not markedly restricted by the national party. There are many indications that national party leaders do not have the power to control effectively the nominating processes in subnational party organizations and to promote candidates who are opposed by local or Land party organizations. In 1983, for example, the SPD's national leaders failed to secure the nomination of former federal Chancellor Willy Brandt as the leading candidate on the Rhineland-Palatinate Landesliste. In this case, as in many others, restrictions on the autonomy of the Land party organizations emerge primarily from decisions previously made by the local organization. Even the nomination of the candidates for the Landeslisten is largely a result of bargaining between local and regional party elites. ${ }^{12}$

Apart from their function as means of selecting the Land assemblies and governments, elections in the Länder serve increasingly as "midterm elections" in national politics. Leaders of the national party branches participate in Land campaigns, and frequently claim Land elections to be a vote on the conduct of the national government. ${ }^{13}$ Many voters seem to have adopted this approach to Land elections, too, because only a small minority of the electorate evaluates the performance of the Land party independently from the national government's performance. Voters generally perceive Land and national parties as homogeneous policymaking organizations; consequently, they use their ballot in Land elections as an instrument for protesting or supporting the national government's policies. As Rainer Dinkel has shown, the parties running the national government normally suffer losses

\footnotetext{
${ }^{12}$ Peter Haungs, Parteiendemokratie in der Bundesrepublik Deutschland (Berlin: Colloquium Verlag, 1980), pp. 36-41; and Heino Kaack, Geschichte und Struktur des deutschen Parteiensystems (Opladen: Westdeutscher Verlag, 1971), pp. 595-645.

${ }^{13}$ Rainer Dinkel, "Der Zusammenhang zwischen Bundes- und Landtagswahlergebnissen," Wahlsoziologie heute: Analysen aus A nlass der Bundestagswahl 1976, ed. Max Kaase (Opladen: Westdeutscher Verlag, 1977), pp. 349, 355-356; for a more detailed analysis, see Georg Fabritius, Wechselwirkungen zwischen Landtagswahlen und Bundespolitik (Meisenheim am Glan: Hain, 1978).
} 
in Land elections. These are more marked at mid term than at the beginning or the end of the legislative session of the national parliament. ${ }^{14}$

Because national and Land elections normally are held in different political settings, it is difficult to explain the causes of different vote shares of political parties in either type of election. In 1983, Land and national elections were held on the same day in the Rhineland-Palatinate (i.e., under identical political circumstances). This provides an opportunity to explore the degree of correspondence between electoral results in Land and national elections. As Table 1 shows, neither turnout nor the vote shares received by the competing parties in Land and national elections differed markedly. Turnout was identically high for both electoral contests ( 90.4 percent). The two major parties, CDU and SPD, fared somewhat better in the Land than in the national election, while the obverse was true in the case of the FDP. The Green party got an equal vote share in both elections. When Land vote shares in the thirty-six counties and independent cities are regressed on the corresponding vote shares in the national election, an almost straight line is displayed indicating a perfect linear dependency of the former on the latter, with up to 99.6 percent of variation of $L$ and vote shares explained by national vote shares. The pattern of the voters' decision in the Land and national elections is largely the same, with some difference remaining in the absolute percentage points of the vote shares in each election in the thirty-six units of analysis. ${ }^{15}$

In addition to an analysis of the Land-related selection of political personnel, the political systems of the separate Länder may serve as points of access to national leadership positions. According to Gerhard Loewenberg and Heino Kaack, however, this pattern of recruitment is the exception rather than the rule. During the period examined by Loewenberg, members of the German national executive (Bundesregierung) were recruited almost exclusively from leading positions in the national parliament. ${ }^{16}$ Only rarely were they recruited from careers in the Land's executive or legislative branches. This description seems still to be valid with regard to most cabinet members, but the situation differs from time to time.

Whether a national executive career typically starts in the Land arena can be analyzed most appropriately in situations where there are major exchanges of national government personnel. In addition to the formation of the first

\footnotetext{
${ }^{14}$ Dinkel, “Der Zusammenhang zwischen Bundes- und Landtagswahlergebnissen"; Rainer Dinkel, "Landtagswahlen unter dem Einfluss der Bundespolitik: Die Erfahrungen der letzten Legislaturperioden," Wahlen und politische Einstellungen in der Bundesrepublik Deutschland. Neuere Entwicklungen der Forschung, eds. Jürgen W. Falter, Hans Rattinger, and Klaus G. Troitzsch (Frankfurt: Lang, 1989), pp. 253-262.

${ }^{15}$ For a more detailed analysis see: Ulrich Sarcinelli, ed., Wahlen und Wahlkampf in Rheinland-Pfalz: Beiträge für die politische Bildungsarbeit aus Anlass der Landiags- und Bundestagswahlen am 6. März 1983 (Opladen: Leske Verlag, 1984), and Peter Haungs and Eckard Jesse, "Die rheinland-pfälzische Landtagswahl vom 6. März 1983: Erste Doppelwahl in der Geschichte der Bundesrepublik," Zeitschrift für Parlamentsfragen 14 (Winter 1983): 517-531.

${ }^{16}$ Gerhard Löwenberg, Parlamentarismus im politischen System der Bundesrepublik Deutschland (Tübingen: Rainer Wunderlich Verlag, Hermann Leins, 1969), pp. 299-318; Kaack, Geschichte und Struktur des deutschen Parteiensystems, pp. 670-673.
} 
TABLE 1

National and Land Elections in Rhineland-Palatinate, 1983

\begin{tabular}{lccccc}
\hline & Turnout & CDU & SPD & FDP & Greens \\
\hline & \multicolumn{6}{c}{ Statewide Election Result } \\
National election & 90.4 & 49.6 & 38.4 & 7.0 & 4.5 \\
Land election & 90.4 & 51.9 & 39.6 & 3.5 & 4.5
\end{tabular}

Regression of Vote Shares of Land Election on National Election

\begin{tabular}{lrrrr} 
Intercept & 3.140 & .190 & -.090 & .417 \\
Slope & .982 & 1.204 & .639 & .918 \\
Variance explained & .989 & .996 & .487 & .817 \\
\hline
\end{tabular}

SOURCE: Statistisches Jahrbuch für Rheinland-Pfalz, 1988/89 (Bad Ems: Statistisches Landesamt Rheinland-Pfalz, 1988), p. 196; computations done by the author.

national cabinet in 1949, major changes have taken place in 1966, 1969, and again in 1982. When the first cabinet of Chancellor Konrad Adenauer was formed, six of fifteen cabinet members had belonged to a Land government, with two of them (Wildermuth and Seebohm) directly changing from a position in the Land government to the Bonn Cabinet. As Löwenberg points out, Adenauer deliberately left out leading politicians from the Länder in selecting the members of his cabinet. ${ }^{17}$ In the Grand Coalition Cabinet of Chancellor Kurt Georg Kiesinger (1966-1969), eleven of nineteen members did not belong to the previous administration, and seven of them had held a Land government position some time before. However, only three were recruited directly from a Land executive (Kiesinger, Willy Brandt, and Lauritz Lauritzen). ${ }^{18}$ Even more limited was the recruitment function of the Land governments with regard to the first cabinet of Chancellor Willy Brandt (1969). It was comprised of eleven newly appointed members, only one of whom, Helmut Schmidt, served as a Land cabinet minister in the early 1960s. Before entering the cabinet, he was the influential leader of the SPD parliamentary group. When the CDU/CSU-FDP coalition government headed by Chancellor Helmut Kohl was formed in 1982, only three of its seventeen members-all FDP cabinet veterans in the SPD-FDP coalition government-belonged to the previous administration. Four of the newly appointed officials had held positions in a Land government (Chancellor Kohl and Ministers Geissler, Blüm, and Stoltenberg), the latter two coming directly

\footnotetext{
293.

${ }^{17}$ Löwenberg, Parlamentarismus im politischen System der Bundesrepublik Deutschland, p.

${ }^{18}$ Kaack, Geschichte und Struktur des deutschen Parteiensystems, pp. 512-513.
} 
from there.

As these examples show, the recruitment function of the Land government for the national executive varies considerably over time. However, a direct move from Land to national executive positions is not firmly institutionalized in West Germany. The limited relevance of this recruitment pattern becomes even more apparent if compared with the role that leading parliamentary positions play in the recruitment of future cabinet members. This may be demonstrated by analyzing the political background of members of the incumbent Bonn cabinet. Only one of its members, Ursula Lehr, did not have any parliamentary or executive experience before she was appointed as minister of family affairs. Two members belonged to the Bundestag without having any leading function in the national parliament prior to their appointment as members of the government. Only two were immediately recruited from a Land government without having had any kind of parliamentary career (Scholz and Töpfer). Nine cabinet members occupied some parliamentary leadership positions before being selected for a leading executive function, and three previously had Land government as well as parliamentary leadership experiences (Chancellor Kohl, Stoltenberg, and Blüm). In summary, the most important precondition to being selected as a member of the national government is a parliamentary career. It can be argued, then, that the political system of the Federal Republic of Germany increasingly has adopted the features of a parliamentary party state.

The function of the Länder as a starting point for a national executive career is demonstrated most clearly with regard to the offices of federal chancellor and leader of the opposition. Only Chancellor Konrad Adenauer did not hold any kind of leading executive position in a Land government before he entered the national government. Each of his five successors moved more or less directly from a top position in a Land executive to the office of federal chancellor or opposition leader. With only one exception since 1961, all opposition candidates for federal chancellor were prime ministers (Ministerpräsidenten) of a Land. ${ }^{19}$

A far more intense exchange of leadership positions exists between the national and Land party organizations. This is especially apparent in the CDU. Five members of the party's top executive organ, the Parteipräsidium, hold simultaneously the position of chairman of one of the Land party organizations. Nearly all of them are, or were, leading figures in the executive or legislative bodies of a Land. The chairmen of five of the six remaining Land party organizations are represented in the larger executive organ, the Bundesvorstand. Occupying a top position in the political system of the Länder is one of the most important preconditions to being elected as a member of the party elite at national conventions. The same is true to a lesser degree for the SPD and for the FDP. (The statute of the Green party pro-

\footnotetext{
${ }^{19}$ All dat a relating to cabinet formation at the national and the Land level were drawn from Peter Schindler, Datenhandbuch zur Geschichte des Deutschen Bundestages 1949 bis 1982 (3rd rev. ed.; Baden-Baden: Nomos, 1984), pp. 372-388.
} 
hibits any accumulation of leadership positions.) It is clear that the internal structure of German political parties, organizationally as well as with regard to elite-recruitment patterns, is strongly federal. ${ }^{20}$

To summarize, the political system of the Länder serves in a variety of ways as a starting point for national political careers, depending on the type of national position. Politicians holding regional leadership positions frequently move up to the national party elite, while tending to retain their role in the Land political system. This combination of leadership positions serves as an important means of promoting communication and cooperation between the various branches of the national party, but it contributes to an enormous intraparty concentration of political power as well. It is not easy to make a clear judgment as to whether this kind of intraparty cooperation has a negative or a positive impact on the autonomy of Land party organizations. On the one hand, it may have a centralizing effect and restrict centrifugal tendencies in Land party politics. On the other hand, and this seems to be more probable, Land party elites may use their presence in the national party executive organs to exercise influence on the politics of the national party.

A similarly close connection between national and Land leadership positions in the executive and legislative branches of the political system is prohibited by law. Advancement to national executive and legislative offices only rarely starts in the Länder. Nevertheless, the leaders of the national opposition party enjoy, in the short run, only one opportunity to gain experience in executive affairs (i.e., election or appointment to an executive office in one of the Länder). In light of the fact that a major change in government has occurred only three times since the founding of the Federal Republic, this opportunity is important in light of the high evaluation by the German electorate of executive competence as a quality of political leaders. In a federal system, certainly, broader opportunities for acquiring leadership experiences are available than in unitary states. In appraising the positive effect of federalism on the recruitment function of political parties, however, it should also be noted that experience does not necessarily equal competence, and an executive career in the national government does not usually originate in a Land executive branch.

\section{The Formulation and Implementation of Public Policy}

Leadership recruitment and the formulation and implementation of political programs are related party functions. In order to convert party platforms into binding public policy, parties need to control the executive and legislative branches of government. Conversely, party platforms serve as in-

\footnotetext{
${ }^{20}$ See further details in Heino Kaack, "Zur Struktur der politischen Führungseliten in Parteien, Parlament und Regierung," Handbuch des deutschen Parteiensystems: Struktur und Politik in der Bundesrepublik zu Beginn der achtziger Jahre, vol. 1, eds. Heino Kaack and Reinhold Roth (Opladen: Leske Verlag und Budrich GmbH, 1980), pp. 195-219; Kaack, Geschichte und Struktur des deutschen Parteiensystems, pp. 512-514.
} 
struments in a political party's attempt to gain control of the government.

Political parties participate in manifold ways in the process of shaping a society. They aggregate the demands of the electorate, integrate them by formulating more or less comprehensive political programs, and, in turn, present their programs to the electorate. In performing these functions, they contribute to organizing and regulating political competition for the control of governmental power. As majority and minority parties, they share in the legislative process. In controlling the executive, they prepare and implement authoritative public policies. Article 21 of the Basic Law designates these tasks as legal functions of political parties.

Although there is a broad discussion in international political science about whether political parties adequately perform their policymaking function in a federal system, it is by no means clear just what the notion of "influencing the conduct of government" really means in practice. Not only because of conceptual unclarity but also because of serious gaps in comparative empirical research on public policymaking, it is easier to evaluate the parties in their recruitment functions than in their policy-shaping capacity. In contrast to a unitary political system of the British type, the broad diffusion of policymaking responsibilities in federal systems has often been described as a source of immobilism. In unitary systems, the national government and the parliamentary majority supporting the government are not markedly restricted in realizing their policy preferences by countervailing powers. By casting a ballot, the voter allocates governing power to a certain political party, and he or she makes a clear choice between distinct political programs. After having been entrusted with power, the parliamentary majority is expected to implement its program according to the voters' majority decision. In contrast, as a result of various constitutional and legal provisions and of developments in the practice of federalism, the West German national government has to accommodate its policy options to the demands of a large number of actors, each holding specific policymaking responsibilities. ${ }^{21}$

As a great number of case studies concerning cooperative federalism in the Federal Republic demonstrate, there has been a far-reaching intermingling of Land and federal powers. The emerging pattern of federal-Land cooperation clearly goes beyond the provisions for federal cooperation originally found in the Basic Law.

The bulk of national law is passed not only by the Bundestag. The Bundesrat, which represents the Land cabinets in the federal political process, has the right to veto any act passed by the Bundestag affecting the relationship between national and Land authorities. This applies to all areas of public policy that are implemented by the Länder and that involve tax sharing. With a few exceptions, such as foreign and defense policy and international trade, almost all public policies are included in this fusion of legal and administrative competencies. Since 1949, legislative powers have been

${ }^{21}$ Lijphart, Democracies, pp. 169-186. 
assumed increasingly by the federal parliament. As a reaction, the Bundesrat has claimed a comprehensive right of participation in national legislation. This claim is not limited to the implementation of federal law by Land authorities, but includes the policy content of federal legislation as well.

In addition, the past two decades have witnessed the establishment of a large number of institutions in which federal and Land powers are closely interwoven. Among these are the planning boards for the "joint tasks" of the federal and Land governments, the council for public financial planning, and the more or less institutionalized conferences of the leaders of federal and Land departments. Many important areas of public policy are included in this system of cooperation, such as land-use planning, regional economic development, transportation, and urban renewal. ${ }^{22}$

The developments may be seen as undermining to some extent the voters' influence on the formulation and implementation of public policy, since national as well as Land governing parties are not able to implement their (and the majority of voters') policy choices as easily as is supposedly possible in unitary systems. Instead, the national government must accommodate its programs to the needs and demands of other party branches controlling the Länder. The Land governments, in turn, are subjected to federal law in many policy areas, or they have to adjust their policy strategies in areas involved in the system of cooperative federalism to the governments of other Länder. Due to these restrictions, party competition does not work effectively as a means of choosing specific sets of public policies in national and in Land politics.

As a consequence of the need for federal cooperation, the policymaking function of political parties and the concept of responsible party government may be undermined especially when the following conditions are met:

(1) Major differences exist between the political programs of the national majority and the minority parties;

(2) Most Länder are governed by the national minority party or parties whose regional branches follow the policy choices of the national opposition; and

(3) Agreement of the majority of the Länder is required for the realization of federal programs.

All of these conditions are not generally present in German politics. With regard to the first condition, a detailed analysis of the impact of party ideologies on Land policies conducted by Manfred G. Schmidt demonstrates that only in a few areas do the two large competing German parties, CDU/CSU and SPD, have diverging policy profiles. Whereas the issues of public education, law and order, and the scope of the public sector are mat-

\footnotetext{
${ }^{2}$ Laufer, Das föderative System der Bundesrepublik Deutschland, pp. 121-150; Lehmbruch, Parteienwettbewerb im Bundesstaat, pp. 72-124; Rudzio, Das politische System der Bundesrepublik Deutschland, pp. 309-324.
} 
ters of party conflict, this is not characteristic of most issues immediately involved in the cooperative decisionmaking structures. The existing policy differences sometimes attributed to the dynamics of party competition were found primarily in periods of economic growth when political innovations could be implemented without redistributing private incomes. In addition, the emergence of a particular policy profile of a Land government became most probable when Social Democrats continuously dominated that government for a long time and when they did not need to form coalition cabinets. Never did a major policy shift result immediately from a change in government from the CDU/CSU to the SPD or vice versa. ${ }^{23}$

A strong institutional tendency toward a consensual political style exists primarily in legislative cooperation between the Bundestag and the Bundesrat and in the planning boards responsible for "joint tasks" when most administration in the Länder is controlled by the national opposition party. In the areas involved in these cooperative decisionmaking systems, the national administration needs to be supported by a majority of the Land executives in order to implement its programs. Even though party conflicts are sometimes found in the Bundesrat, they are rather exceptional, and the large bulk of federal law is enacted unanimously, even by the Bundestag. The decisionmaking practice of "joint task" planning boards is even more nonpartisan because they perform mainly administrative functions. Their main responsibility is to distribute federal and $L$ and funds which may, of course, be controversial. However, conflicts spring more from regional interests than from diverging ideologies. ${ }^{24}$

Given that the remaining institutions of cooperative federalism do not have decisionmaking authority, and lack the power to require any one of the participants to carry out joint policies that contradict individual policy preferences, their activities do not really impinge on the policy-shaping function of political parties. Conferences of the leaders of Land and federal departments as well as the distribution of federal grants appear to have only a very limited policy-shaping capacity. The issue of educational policy in recent years is a good example of the fact that federal cooperation did not prevent the majority parties in the German Länder from realizing divergent policy preferences. ${ }^{25}$

Research on cooperative federalism in Germany demonstrates that there are some restrictions on the implementation of goals held by the governing party. However, it is unclear whether this is due to federalism. The national

\footnotetext{
${ }^{23}$ Manfred G. Schmidt, CDU und SPD an der Regierung: Ein Vergleich ihrer Politik in den Ländern (Frankfurt, New York: Campus Verlag, 1980).

${ }^{24}$ Fritz W. Scharpf et al., Politikverflechtung: Theorie und Empirie des kooperativen Föderalismus in der Bundesrepublik (Kronberg: Scriptor Verlag, 1976), pp. 81-94, 110-121. On the role of the Bundesrat in the legislative process see Laufer, Das föderative System der Bundesrepublik Deutschland, pp. 69-84; Rudzio, Das politische System der Bundesrepublik Deutschland, pp. 272-281; and Hans-Georg Wehling in this issue.

${ }^{25}$ Lehmbruch, Parteienwettbewerb im Bundesstaat, pp. 153-157; Schmidt, CDU und SPD an der Regierung, pp. 89-112.
} 
administration must promote a consensus-oriented policy style because of factors that exist also in centralized political systems, such as the need for coalition formation in multiparty systems, the requirement of winning the support of various pressure groups, and the political power of the national bureaucracy. Comparative studies might provide some insight into the impact of federalism on the relationship between party politics and policy output. In general, there seems to be a distinctive policy pattern of leftist and rightist administrations. The former favor an expansion of the public sector, especially in the form of large welfare programs, and they are mainly concerned with securing full employment. The latter are interested in limiting public expenditures, their welfare programs are less ambitious, and their prime economic goal is fighting inflation.

Some of the studies conducted so far include centralism/federalism as an explanatory variable. As Frank Castles and Robert D. McKinlay found, unitary states are more active in social welfare policy than are federal states, even after the effect of party variables is controlled. ${ }^{26}$ The interesting question of whether governmental policy output is more strongly influenced by party ideologies in unitary than in federal systems has never been tested adequately until now. A re-analysis of data from Manfred G. Schmidt's research on economic and welfare policy in Western democracies casts serious doubt on the assumption that federalism might prevent the governing party from realizing its ideological preferences. Long-term conservative dominance in government has a fairly similar negative effect on the political regulation of the economy in federal and in unitary states. Because of the small number of cases, however, these results should be interpreted cautiously. ${ }^{27}$ As a result of a change in government, a shift from a more leftist to a more conservative policy profile occurred in centralized political systems like Britain or France as well as in federal states like the United States and Germany.

Another consequence attributed to the emergence of cooperative federalism is a certain lack of political innovation. Party competition is said to have an innovative effect on public policy. It contributes to placing new issues on the political agenda and to opening the political process to the demands of formerly neglected groups. However, political innovations are to be expected only if an innovation-oriented government can exercise control over policy implementation. This also is impeded by the bargaining style of consensual-federal politics, which, in effect, may lead to immobilism. ${ }^{28}$

\footnotetext{
${ }^{26}$ Frank Castles and Robert D. McKinlay, "Does Politics Matter: An Analysis of the Public Welfare Commitment in Advanced Industrial Democracies," European Journal of Political Research 7 (Summer 1979): 174-179; David R. Cameron, "The Expansion of Public Economy: A Comparative Political Analysis,"' American Political Science Review 72 (Winter 1978); 1246-1249, 1251-1255; Manfred G. Schmidt, Wohlfahrtsstaatliche Politik unter bürgerlichen und sozialdemokratischen Regierungen: Ein internationaler Vergleich (Frankfurt, New York: Campus Verlag, 1982), pp. 39-56.

${ }^{27}$ See the data in Schmidt, Wohlfahrtsstaatliche Politik, p. 222, Fig. 27. Kendall's tau c coefficients between conservative/liberal dominance and the political control of the economy are very similar in federal and centralist systems, with -.346 and -.408 , respectively.

${ }^{28}$ Lehmbruch, Parteienwettbewerb im Bundesstaat, pp. 36-42; Arend Lijphart, Democracy
} 
Assessing the innovative effects of party politics under varying institutional conditions in a reliable way is difficult. The studies cited above demonstrate that federalism tends to dampen public spending, especially in the area of welfare. However, whether this is seen as innovative or counter-innovative depends largely on the analyst's ideological preferences. Whatever the meaning of "innovation," innovative programs may be blocked, among other reasons, by bargaining strains inherent in federalism. There exist other, at least equally important, impediments to an innovation-oriented public policy conducted by a national administration - for example, the veto power of influential pressure groups and the general public, conflicts within the administration and within the party, and limited government revenues. It is not by accident that all of these problems have been discussed extensively under the label of the "governability" of Western democracies, and that federalism/centralism has not been a major factor in this discussion. ${ }^{29}$ Federalism does not seem to be of major importance for the policy-shaping functions of political parties in West Germany.

\section{The Integrative Function}

Attracting as many supporters as possible is essential for a political party to win control of the government, and various attempts are made at performing this integrative function. Political parties introduce their followers' policy aspirations into the political process and make them parts of their platforms. They offer participatory devices that enable the public to influence political decisionmaking, and they function as agents of political socialization.

In the search for electoral support, political parties become involved in conflict with other parties pursuing the same goal. Integrative functions, therefore, cannot be performed without friction resulting from tensions between the requirements of party-related and system-related integration. The former implies antagonism between competing parties, the latter calls for a sense of community that includes the leaders as well as the rank and file of the competing parties.

Federal systems are frequently established because of serious integrative problems in the respective societies. Where the various cleavages exist along regional lines, federalism may serve as an adequate mechanism of integrating the regions into an overall political community. ${ }^{30}$ This complementary integrative function of party democracy and federalism may be easily demonstrated with regard to the German party system.

The pre-Nazi party system was strongly fragmented in a twofold manner:

in Plural Societies (New Haven: Yale University Press, 1977), pp. 50-52; Scharpf et al., Politikverflechtung, pp. 20-22, 225-233.

${ }^{29}$ Michel Crozier, Samuel P. Huntington, and Joji Watanuki, The Crisis of Democracy: Report on the Governability of Democracies to the Trilateral Commission (New York: New York University Press, 1975).

${ }^{30}$ Lijphart, Democracy in Plural Societies, pp. 41-47, 87-99; Lijphart, Democracies, pp. 169-186. 
there were many political parties and each was closely tied to separate and narrow segments of the social cleavage structure. Contrary to many other modern states, a constitutional cleavage was a constitutive element of party conflict. Legitimacy was not granted to the political system by some major parties during the German Empire or during the Weimar Republic. ${ }^{31}$

Following the foundation of the Federal Republic, patterns of party cleavage have been simplified by the formation of the CDU and CSU, which united the previously separated Catholic and Protestant sectors of society. Similarly, the rightist and leftist branches of Liberalism became integrated into the FDP. However, the traditional antagonism between German parties did not disappear immediately. During the early 1950s, almost all important political issues were matters of bitter party conflict. This was true especially for the new economic order, the question of rearmament, and the integration of Germany into the Western Alliance. The SPD national minority party was unable to secure adoption of its proposals on any of these issues. Because its minority position lasted from 1949 to 1966 , the complete failure to influence the conduct of public policy could easily have estranged its partisans from the political system.

This did not happen for several reasons. Because the Social Democrats controlled the administration of several Länder during this period, they had an opportunity to realize some of their goals, at least in Land politics. From 1949 to 1966, two Länder, Hesse and Bremen, were continuously governed by the Social Democrats, and so were West Berlin and Hamburg for most of the time. Only in the Rhineland-Palatinate were they without any role in forming a government after 1949. The Christian Democrats continuously controlled the administrations of the Rhineland-Palatinate, Bavaria, Schleswig-Holstein, and Baden-Württemberg, even after they had lost power at the national level in 1969. ${ }^{32}$ In spite of the fact that substantial changes in the national government involving the two leading parties occurred only three times, a share of executive power in the political system of the Länder has made an important contribution to the integration of the supporters of the minority party into the political community.

Federal systems enable political parties to perform their integrative function in still another way. In the Länder, coalitions may be formed of political parties which are adversaries in the national political system. Indeed, since 1949, coalition patterns in the Länder have displayed a greater variety than

\footnotetext{
${ }^{31}$ Lehmbruch, Parteienwettbewerb im Bundesstaat, pp. 19-24; and Lijphart, Democracy in Plural Societies, pp. 15-16.

${ }^{32}$ Riker, Federalism, pp. 137-142, offers a somewhat more sophisticated concept to measure the federal diffusion of power, an index of disharmony which is designed to measure the extent of control exerted by the national governing party over the executive of the constituent Länder. It ranges between zero (when the national majority party controls the executive of all constituent Länder) and one (complete absence of subnational executive power of the national majority party). The application of Riker's index to West Gemany is somewhat complicated by the existing multiparty system. In the period of 1950-1966 (control of the national government by the CDU/CSU), it varied between .38 and .55 ; for the period between 1970 and 1982 from .43 to a high of .64 , and between .36 and .45 since then.
} 
has been the case in national politics. In four Länder, "Grand Coalitions" made up of Christian Democrats and Social Democrats were in office for several years (West Berlin, Lower Saxony, Baden-Württemberg, and the Saarland). In other Länder, Christian Democrats shared in a coalition with parties that were part of the national opposition, while Social Democrats co-governed with minor national governing parties, especially with the FDP. An interesting, but short-lived, experiment in integrating a marginal party was the SPD/Green coalition in Hesse in the mid-1980s. Another example is the SPD/Green coalition since the winter of 1989 in West Berlin. Thus, Land politics may serve as an experimental field for national coalitionbuilding. New patterns of party coalitions bringing about a change in national government were initiated first in some of the Länder, examples of which are the formation of an SPD-FDP coalition in North-Rhine Westphalia in 1966, and a CDU-FDP administration in Lower Saxony in 1977 and in the Saarland in 1980. During the last twenty years, however, coalitions in the Länder have conformed increasingly to the national pattern. Coalitions formed by the Liberals and Christian Democrats were rare exceptions between 1969 and 1982, as have been Social Democrat/Liberal coalitions since 1982.

\section{CONCLUSION}

Federalism does not consistently impinge on the performance of political parties in a democracy. Federal diffusion of power improves the recruitment function of political parties, although the political system of the Länder could probably serve even better as a recruitment base for national political leaders than is actually the case.

The formation and implementation of public policy are often said to have become more difficult than in previous decades. Federal bargaining processes may have contributed to this development, but they are by no means the sole reason for the problems national administrations confront when implementing their policy choices. It remains rather unclear as to what degree federal cooperation really interferes with the policymaking functions of party government, especially since there is an increasing strain on intraparty and intra-administrative bargaining. Due to a changing social composition and an increasing ideological diversification among their members and followers, German political parties have become far more pluralistic organizations than they were previously. Therefore, many of the difficulties attributed to the tension between party competition and federalism are rooted in the party system itself.

The most important effect of federalism on the working of party democracy relates to the integrative function of political parties. The federal distribution of political power provides the national minority party with opportunities to share in governing the country. This is an essential contribution to the integration of its leaders and followers into the national political community. 